\title{
Man as Object. The Denial of Dignity
}

\author{
PhD. Vereno Brugiatelli
}

\begin{abstract}
Considering and treating people as things, objects or instruments is easier than one may think. Marx and Lukacs have highlighted the fact that the different processes of reification (reducing man to an object) is rooted in market logic: philosophers of the Frankfurt School like Horkheimer, Marcuse and Adorno have identified their origin in the techno-scientific reasoning of capitalist society. In this paper I intend to demonstrate that their explanations embrace the phenomenon of reification in an incomplete way. Through Axel Honneth's social philosophy I intend to show that the reduction of man to an object depends on the misrecognition of the qualities and dignity of man. Such misrecognition does not depend on market logic or techno-scientific reason, but rather on a certain attitude that man adopts towards himself and others.
\end{abstract}

Keywords: Man as Object, Reification, Capitalist society, Market, Misrecognition.

\section{Introduction}

In the first part of this study I will examine the phenomenon of Reification (reducing man to an object) from the point of view of the studies carried out by G. Lukacs and the philosophers of the Frankfurt School, who reached the conclusion that this phenomenon is deeply rooted in the logic of the market and in the techno-scientific reasoning of capitalist society. To reconstruct the fundamental stages of their analysis, I will focus on the economic, social and cultural dynamics, which they believe to be the basis of the processes of reification. Thereafter, I will compare their position to Axel Honneth's perspective to demonstrate that such processes cannot only be attributed to market logic. From his viewpoint, the different forms of reification imply relational dynamics characterised by the absence of emotional involvement with regard to the sentiments felt and demonstrated by others. Reification derives from the cancellation of relationships based on sentimental participation of what other people are experiencing.

\section{The market as a cause of reification}

In Grundlegung zur Metaphysik de Sitten, Immanuel Kant affirms the necessity of treating human beings as ends rather than as means. Considered as means, human beings are treated as objects, as things to be used. "So act as to treat humanity, whether in thine own person or in that of any other, in every case as an endwithal, never as means only" (Kant, 1909: 47). At the beginning of the 1920s Gyorgy Lukacs, in Geschichte und Klassenbewustsein (1923), elaborated the concept of reification. The Hungarian philosopher clearly emphasises that man and social relations in a capitalist society are "reificied", reduced to things. This phenomenon, which he named reification, was analysed by Marx in Okonomischphilosophische Manuskripte in 1844, who described it as "alienation". It has been said that Lukacs took up the Marxist concept of alienation and reused it. However, what is surprising is that the Manuskripte were unpublished until 1932, therefore making it impossible for Lukacs to have consulted them while he was writing his Geschichte und Klassenbewustsein published in 1923. Thus, while being able to reference other Karl Marx works and studies by Max Weber, his work was original.

Quoting Marx, Lukacs explains that reification occurs when "a relationship between people takes on the character of a thing". In his opinion, the progressive spread of this phenomenon is a principle of capitalist societies and is deeply rooted in the exchange of goods, which man does not control but is controlled by it. In the exchange of merchandise everything, including man, is considered as a source of profit. Man's abilities are perceived in view of profit. In this way, in a capitalist society the only people who count are those who have the suitable abilities to generate and maximise profit. Work is reduced to goods and with it the worker obeying, like all other goods, the laws of market demand and supply. This reality of mutual consent leads man to relate to others as goods. 
Lukacs uses the term "as goods" to define the instrumental use of people, the consideration given to their abilities and needs. In such a world, according to the Hungarian philosopher a truly critical and practical approach cannot exist since "contemplative knowledge" is dominant and dictates conscience and science by elaborating strategies and conditions to favour profit optimisation. By "contemplative knowledge", Lukacs does not mean that the knowing subject is absorbed in involved and interested reflection with regard to what is being analysed, but, to the contrary, he implies a detached, uncaring, neutral and uninvolved behaviour. Such an approach is characteristic of the Scientist, whose thought is reificying and reificied and is dictated by calculation based on the distinction between subject and object, between theory and practice.

According to Lukacs, critical thought is possible only through dialectics considered not as a universal law of nature but as interaction between subject and object, theory and practice and their unity. Dialectics allows us to understand that the reification of man is not a natural fact but it is the historical-ideological product of certain activities of man such as those dictated by capitalist logic.

In Lukacs' opinion, in capitalism this reificying process exists on such a vast scale that it has penetrated the conscience of man who has acquired the habit of perceiving himself, his feelings, others and all living beings as "things", as simple objects. For this reason, Lukacs states decisively that reification has become "man's second nature". He identifies its origin in the market logic of a society dominated by the capitalist middle class. This point of view was taken up by the philosophers of the Frankfurt School in light of the assertion of instrumental reason in the modern era.

\section{Technical-scientific reason and reificying processes}

The concept of "reification", analysed by the philosophers of the Frankfurt School together with the rediscovery of Lukacs' ideas, was widely adopted, often to extremes, in the 1968 intellectual debate.

Horkheimer, Marcuse, Adorno and Habermas agree with the claim that contemporary society is dominated by a technical and scientific rationality that pursues a reificying approach with the aim to dominate the world. Their concept of reason recalls that defined by Max Weber. In his work Industrialisierung und Kapitalismus im Werk Max Weber (included in the Kultur und Gesellschaft, 2, collection, 1965), Herbert Marcuse highlights the connection established by Weber between reason, capitalism and dominion.

The specifically Western idea of reason is fulfilled in a system of material and intellectual civilisation -economy, technology, "way of life", science, art- which is fully developed in industrial capitalism, and this system tends towards a specific type of dominion, which becomes the destiny of the present age: total bureaucracy. Reason unfolds as technical reason, as transformation and manipulation of men and things due to the systematic-scientific apparatus, built upon the predictable capacity to perform; the rationality of such apparatus organises and controls things and people, factories and administrative bureaucracy, work and leisure time.

Marcuse states that in Max Weber's sociology, formal rationality becomes capitalistic rationality; so it presents itself as that methodical organisation of the irrational "profit impulse. In this work of 'organisation' Western reasoning becomes the economic reason of capitalism: the rational and continuous tendency towards renewed profits in the field of capitalist endeavour. Therefore, rationality becomes the condition of profitability, based on systematic and methodical calculation, on the "calculation of capital". Thus, it is not difficult to recognise the different phenomena of reification produced by technical rationality, which acquires the features of economic reason of capitalism. In Dialektik der Aufklarung (1947), Horkheimer and Adorno (2007) observe that scientific reason reduces nature, life and man to objects of analysis in order to dominate and manipulate them as required. It constitutes a formidable instrument of capitalism which, with the invention of the "culture industry" with its channels of entertainment and distraction, kills critical reasoning and annihilates that reason which pursues the liberty and emancipation of man from all forms of reification and alienation.

Technocratic rationality leads to indifference and passivity, acceptance and submissiveness to the status quo. Upon the reification of reality is based technical and scientific reason, which is seen to be increasingly formal and commanding in character, indifferent to nature and life, and instrumental in the subjugation of man. Horkheimer claims in Zur Kritik der instrumentellen Vernunft (1967) that with the modern industrialised civilisation, instrumental and calculating reason appeared as irrational dominion over man and nature. Such a capitalistic society reflects the contradictions of instrumental reason: it possesses the means and technological-scientific tools to eliminate material misery and to make man happy but, in actual fact, it does none of these. For this reason, according to Horkheimer, capitalism is an irrational system. He 
observes that an individual was once able to see reason as an instrument of self; now he finds himself faced with the reversal of this reification of self. The driver of the car has been thrown out while the car is blindly racing into space. At the pinnacle of the process of rationalisation, reason has become stupid and irrational (Horkheimer, 1967).

\section{What is instrumental and reificying reason based on?}

In a capitalistic society technical reasoning, in its most powerful form, is implemented to manipulate, to control, to monitor, to punish the masses and to provoke a "sense of interior emptiness" which is recognised only superficially and distortedly as lacking material goods. Besides technical reason, a capitalist society is allied with political thought, which depends on the economic-financial and technical sectors in its decision-making process.

A detached approach towards reality, typical of instrumental and scientific reason, fosters capitalistic logic in the sense that instrumental reason treats everything in a neutral manner placing man, animals and embryos on the same level: that of things. With its impassivity and neutrality instrumental reason sees the world in an uninvolved way, downplaying the fact that being a human in the world consists in a sort of existential involvement, in an interested, concerned and practical relationship. Instrumental, scientific and technical reason positions the world as object in opposition to subject (Heidegger, 1980, Pansera, 1998). Heidegger claims that representing (vorstellen), establishing (stellen), organising (bestellen) and producing (herstellen) are essential to technical reason given the power over nature (2013). Reification is the natural consequence of such technical configuration (Vattimo, 1997: 66).

\section{Reification as forgetfulness of recognition}

In his work entitled Verdinglichung (Reification) (2005), Honneth observes that, like Lukacs, Heidegger is convinced that the primacy of the idea of a neutral representation of reality is responsible for the ontological blindness which has prevented adequate understanding of the structures of human existence. According to Honneth, for both philosophers, despite their different perspectives, it is possible to acknowledge the intention to destroy the concept of a knowing and contemplating subject that places the world before self, otherness. Such a configuration is characterised by a distinct separation between the knowing subject and the otherness of other people. In this sense, according to Honneth, it cancels any form of original relationship between man and the world based on emotional involvement.

For Lukacs reification produced by the market highlights a distortion of that original approach through which man establishes social relations. In his opinion it is a mistaken practice based on subject-object dualism and promoted by a contemplative and uninvolved behaviour. Considering Marx's structure-superstructure relationship, Lukacs believes that the economic sphere conditions and shapes cultural and social phenomena. According to Honneth, Lukacs' emphasis, by attributing the processes of reification to the processes of exchange, excludes a significant class of phenomena of reification such as that emerging from the diverse forms of brutal dehumanisation such as racism and human trafficking. What does this missing consideration derive from? For Honneth it derives from a sort of systematic blindness which depends on prejudice whereby only economic obligations can lead to the negation of the human characteristics of man (Honneth, 2005). In his opinion, the phenomena of reification can be traced back to human behaviours that do not originate from a capitalistic context but, rather more, from an approach aimed at cancelling forms of relations characterised by the "recognition" of a person's qualities and dignity. Such cancellation becomes possible when a neutral and detached attitude towards others dominates. By "recognition" Honneth refers to "attitudes and practices by which individuals or social groups are affirmed in certain of their qualities" (Honneth, 2002: 505). He thinks that "acts of recognition are oriented not towards one's own aims but rather towards the evaluative qualities of other" (Honneth, 2002: 513). In interpersonal relationships, when a sentimental dimension or sense of involvement with regard to what others are experiencing is lacking, the emergence of reificying behaviours is always possible.

\section{Conclusion}

In accordance with the analyses of Lukacs and the thinkers of the Frankfurt school such as Horkheimer, Marcuse, Adorno and Habermas (1981), many present-day observers and critics argue that the market has taken possession of our thought processes and our deepest aspirations to the extent that, as stated by Umberto Galimberti, we no longer know how to extricate ourselves from the market and we only know how to see what looks like a good: "Our lifestyle is suffocating in a reasoning made up of calculation, market, exchange, interests and assurances to conserve that withering treasure: life without beauty" (Galimberti, 2008: 123). Judgements, like: in a capitalistic world where social relations are dominated by calculating economic rationality and maximum profit-making, man loses his humanity, are now shared by people of differing 
cultural backgrounds. For Axel Honneth this perspective does not explain the root of the varied phenomenon of reification. His analysis shows that reificying dynamics become a fundamental and dominating part of a society regarding the way in which human relations lack emotional involvement, feelings of solidarity and sentimental interest.

\section{References}

[1 ] Galimberti, U. (2008). II segreto della domanda. Milano: Apogeo.

[2] Habermas, J. (1981). Theorie des kommunikativen Handelns. Frankfurt am Main: Suhrkamp, 2 voll.

[3] Heidegger, M. (1980). Holzwege. Frankfurt am Main: V. Klostermann.

[4] Heidegger, M. (2013). Die Frage nach der Technik. München: GRIN Verlag Gmbh.

[5] Horkheimer, M. (1967). Zur Kritik der instrumentellen Vernunft. Frankfurt am Main: S. Fischer Verlag GmbH.

[6] Horkheimer M. - Adorno T.W. (2007). Dialektik der Aufklärung. Frankfurt am Main: S. Fischer Verlag.

[7] Honneth, A. (2002). Grounding recognition: A Rejoinder to Critical Questions. Inquiry: An Interdiscinary Journal of Philosophy, 45 (4), 499-519.

[8] Honneth, A. (2005). Verdinglichung. Suhrkamp Verlag, Frankfurt am Main, 2005.

[9] Kant, I. (1909). Fundamental Principles of the Metaphysics of Morals, in Kant's Critique of Practical Reason and Other Works on the Theory of Ethics, 6th edition (T. K. Abbot, ed.). London: Longmans.

[10] Lukács, G. (1923). Geschichte und Klassenbewußtsein. In Id. (1979). Werke vol. 2, Frühschriften II, Neuwied-Berlin: Luchterhand, 79-117.

[11] Marcuse, H. (1965). Industrialisierung und Kapitalismus im Werk Max Weber. In Kultur und Gesellschaft, 2. Frankfurt am Main: Suhrkamp Verlag, 107-129.

[12] Pansera, M.T. (1998). L'uomo e i sentieri della tecnica. Heidegger, Gehlen, Marcuse. Roma: Armando.

[13] Vattimo, G. (1997). Tecnica ed esistenza. Torino: Paravia. 